\title{
Preparation and Quality Evaluation of Mango based Whey Beverage
}

\author{
SABIRA PANDEY* AND PRAVIN OJHA \\ National College of Food Science and Technology, Khusibu, Kathmandu, Nepal
}

This study aims to develop a beverage incorporating whey and mango pulp. Beverage was prepared by blending whey and mango pulp in a ratio of 59.9:30, 64.9:2, 69.9:20 and 74.9:15 (with 10\% sugar and 0.1\% CMC at 0.3\% acidity level). Among the treatments, best formulation of the beverage (based on sensory property) was found to be the whey and mango pulp ratio of 69.9:20 with 10\% sugar and 0.1\% CMC.

Key words: Whey, Mango, Beverage, Preparation, Quality Evaluation

\section{Introduction}

Milk comprises carbohydrates, proteins, vitamins, minerals, and fat those are used by the body to maintain health. It contains almost $3.5 \%$ protein, $80 \%$ of which is casein and $20 \%$ are whey proteins. Different types of whey include reduced lactose whey, demineralized whey, acid whey and sweet whey. According to its average composition whey is approximately $93 \%$ water and contains about $50 \%$ of total solids present in the milk and constitute less than $1 \%$ of dry matter (Beucler et al., 2005). The two major whey proteins are $\beta$-lacto globulin and $\alpha$-lactalbumin (Dalgleish et al., 1997) which account for $70-80 \%$ of all whey protein. Whey based beverages boards a wide range of consumers - from old people to little children. Because of its health benefits, it was used to treat some illness, such as tuberculosis and skin and digestive tract diseases, since the time of Ancient Greece (Popović- Vranješ and Vujičić, 1997). As the whey consists of high amount of proteins, it has high nutritional value. Due to this benefit, these beverages are ideal source of energy and nutrients for athletes. Whey proteins are a rich source of branched chain amino acids (BCAA) like isoleucine, leucine and valine. BCAAs unlike other essential amino acids are metabolized directly into the muscle tissue and are first amino acids used during periods of exercise and resistance trainings (Sherwood et al., 2007).

The whey has potential benefits and so it's growing awareness has dragged considerable amount of attention for the development of beverages based on whey. These products have high value in the market place. These beverages have great nutritional quality and increased energy value. These could be principally advantageous in place where there is lack of food and inadequate nutrition that has been causing deficiencies of certain nutrients. Whey is basically, the watery liquid remaining after milk has been coagulated and strained. It consists of almost half of the total solids of milk and is highly a precious source of nutrients like whey proteins, lactose, milk salts and most of water-soluble vitamins (Naik et al., 2009). Whey possesses preventive and curative elements and is particularly used to treat a wide variety of ailments such as arthritis, anemia and liver complaints (Cruz et al., 2009).Thus, incorporation of whey into various beverage and developments of whey drinks using numerous technological approaches have been attempted by large number of researchers (Kravchenko, 1988).

Many efforts have been made in development of beverages with addition of fruit concentrates in order to produce a drink with acceptable sensory properties especially regarding flavour (Koffi et al., 2005). Yadav et al., 2010 conducted a study on development and storage of whey-based banana herbal beverage; Ingale et al., 2009 developed a whey based custard apple beverage. Similarly, Patel et al., 2006 developed a whey based mango herbal (ginger) beverage and Shekilango et al., 1997 prepared whey based beverage from acid whey and over ripe bananas. This study aims to utilize the byproduct i.e whey to develop a nutritious beverage by incorporation of mango pulp in it.

\section{Materials and methods}

Materials- Whey as a byproduct of paneer and stabilizer (Sodium Alginate) used were from the Quality Control Lab of ND's Dairy Pvt. Ltd, Lalitpur, Nepal. Mango variety Kesar and sugar were collected from local market of Kathmandu.

Preparation of Whey Beverage- Four different mango beverages were prepared according to the formulations (Sakhale et al., 2012) shown in Table 1. Beverages was prepared as per the protocol given in Fig 1.

\section{Table 1}

Recipe for preparation of whey based mango beverages $(1000 \mathrm{ml})$

\begin{tabular}{lcccc}
\hline \multicolumn{1}{c}{ Ingredients } & A & B & C & D \\
\hline Mango pulp $(\mathrm{ml})$ & 300 & 250 & 200 & 150 \\
\hline Sugar $(\mathrm{g})$ & 100 & 100 & 100 & 100 \\
\hline Stabilizer & 01 & 01 & 01 & 01 \\
\hline Whey $(\mathrm{ml})$ & 599 & 649 & 699 & 749 \\
\hline
\end{tabular}

Chemical Analysis- The whey, mango pulp and juice were analyzed in triplicate for chemical properties. The total acidity was calculated in terms of lactic acid for whey and citric acid for mango pulp by titrating against $0.1 \mathrm{~N} \mathrm{NaOH}$. The TSS, total sugar \& reducing sugar, and ascorbic acid were analyzed as per Ranganna, 2008. The $\mathrm{pH}$, protein, SNF were determined by Ranganna, 2008 and fat was determined by Gerber's centrifuge method. Caroteniod content of mango was determined by Rainha et al., 2011. 


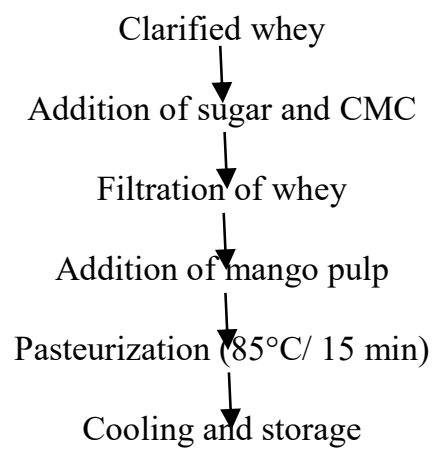

Fig 1. Flow chart for the preparation of mango based channa whey beverage

Sensory evaluation- The beverage samples were taken for the sensory evaluation of beverage. The characteristics of fresh beverage samples were evaluated by a semi-trained panel of 10 judges on a 9-point hedonic rating scale for color, flavor, taste, body and overall acceptability according to Ranganna (2008).

Statistical analysis- IBM SPSS Statistics Version 20 and Microsoft Office Excel 2007 were used for the statistical analysis. The data were analyzed by one-way Analysis of variance (ANOVA) (no blocking), Post Hoc (Duncan) test using SPSS programming at 5\% level of significance. The significance differences between them were studied by using L.S.D at $5 \%$ level of significance.

\section{Results and Discussions}

Physio-chemical composition of whey and mangoByproduct whey was obtained and a random variety of mango was used. These were analyzed for their composition by using methods and methodology described above and the results obtained as shown in Table 2.

Table 2

Physio-chemical analysis of whey and mango

\begin{tabular}{lcc}
\hline \multicolumn{1}{c}{ Composition } & Paneer whey & Mango \\
\hline Acidity $\%$ & $\begin{array}{c}0.22 \pm 0.015 \text { (as } \\
\text { lactic acid) }\end{array}$ & $\begin{array}{c}0.24 \pm 0.006 \text { (as } \\
\text { citric acid) }\end{array}$ \\
\hline $\mathrm{pH}$ & $5.28 \pm 0.029$ & $5.1 \pm 0.010$ \\
\hline Ascorbic acid mg/ & - & $24.1 \pm 0.21$ \\
$100 \mathrm{~g}$ & & - \\
\hline Fat $\%$ & $0.59 \pm 0.36$ & - \\
\hline SNF\% & $5.40 \pm 0.16$ & - \\
\hline Protein $\%$ & $0.41 \pm 0.029$ & $15.00 \pm 0.00$ \\
\hline $\begin{array}{l}\text { Total Soluble } \\
\text { solids }{ }^{\circ} \text { Brix }\end{array}$ & $6.93 \pm 0.11$ & $9.88 \pm 0.103$ \\
\hline Total sugar\% & $4.62 \pm 0.020$ & $5.16 \pm 0.103$ \\
\hline Reducing sugar\% & $4.4 \pm 0.510$ & $9.29 \pm 0.200$ \\
\hline Carotenoids mg/ & - & \\
$100 \mathrm{~g}$ & & \\
\hline Valus are the Means & Standard & \\
\hline
\end{tabular}

Values are the Means \pm Standard deviation (SD) obtained from triplicate data.
The Table-2 clearly indicates that whey and mango pulp were as expected rich in SNF and ascorbic acid respectively. Mango pulp had high TSS, total and reducing sugars contents whereas whey had high protein, SNF, fat and total solids, as compared. The results obtained with respect to chemical characteristic are in agreement with the earlier studies (Ingale et al., 2009; Sarvana \& Manimegalai, 2005).

Physio-chemical composition of beverage- The physiochemical composition of whey-based mango beverage was analyzed after pasteurization and the results are shown in Table 3. Statistical analysis (One-way ANOVA) was carried out for all the parameters and it showed that four different juice formulation processes had significant effect on their physio-chemical properties. It showed that for all parameters four different samples were significantly different from each other except for acidity. In case of acidity, Products B, C and $\mathrm{D}$ were not significantly different while A was significantly different than other three.

Table 3

Physiochemical properties of beverage

\begin{tabular}{lcccc}
\hline \multicolumn{1}{c}{ Parameter } & $\mathrm{A}$ & $\mathrm{B}$ & $\mathrm{C}$ & $\mathrm{D}$ \\
\hline Acidity $(\%$ & $0.30 \pm$ & $0.30 \pm$ & 0.30 & $0.30 \pm$ \\
citric acid) & $0.01^{\mathrm{a}}$ & $0.01^{\mathrm{a}}$ & $\pm 0.01^{\mathrm{a}}$ & $0.00^{\mathrm{a}}$ \\
\hline Ascorbic acid & $10.7 \pm$ & $9.8 \pm$ & $7.1 \pm$ & $6.6 \pm 0.02^{\mathrm{d}}$ \\
(g/100g) & $0.05^{\mathrm{a}}$ & $0.04^{\mathrm{b}}$ & $0.05^{\mathrm{c}}$ & \\
\hline Total sugar & $15.7 \pm$ & $15.5 \pm$ & 15.2 & $14.9 \pm$ \\
& $0.02^{\mathrm{a}}$ & $0.02^{\mathrm{b}}$ & $\pm 0.04^{\mathrm{c}}$ & $0.02^{\mathrm{d}}$ \\
\hline Reducing & $4.17 \pm$ & $4.13 \pm$ & $4.1 \pm$ & $4.01 \pm$ \\
sugar $(\mathrm{g} /$ & $0.01^{\mathrm{a}}$ & $0.02^{\mathrm{b}}$ & $0.01^{\mathrm{c}}$ & $0.02^{\mathrm{d}}$ \\
100g) & & & & \\
\hline TSS ( $\left.{ }^{\circ} \mathrm{Bx}\right)$ & $19.2 \pm$ & $18.6 \pm$ & $18.1 \pm$ & $17.5 \pm$ \\
& $0.28^{\mathrm{a}}$ & $0.05^{\mathrm{b}}$ & $0.11^{\mathrm{c}}$ & $0.05^{\mathrm{d}}$ \\
\hline
\end{tabular}

Values are the Means \pm Standard deviation (SD) obtained from triplicate data. Different letters in the same row indicate significant differences $(\mathrm{p}<0.05)$. A, B, C and D indicate juice made from different combination of whey and pulp ratio i.e. 59.9:30, 64.9:25, 69.9:20 and 74.9:15 respectively.

The mango beverage prepared from different blend ratios of whey and mango showed variations in physiochemical properties accordingly. The ascorbic acid and reducing sugar were found to be decreasing as the amount of pulp was reduced and whey was increased. Similar results have been obtained by Sakhale et al., 2012. Similarly, the total sugar and TSS were also found to be in decreasing order with the increase in whey ratio to that of mango.

Sensory evaluation of mango beverage- Sensory evaluation of trial compositions were carried out to find the best proportion of ingredients through sensory evaluation. The products developed were different at various blend ratios of whey and mango; A (59.9:30), B (64.9:25), C (69.9:20) and D (74.9:15). The products developed were evaluated on the basis of color, flavor, taste, body and overall acceptance. The results obtained by sensory evaluation are given in Figure 2. It is clear that, with the increase of whey in the blend ratio, the 


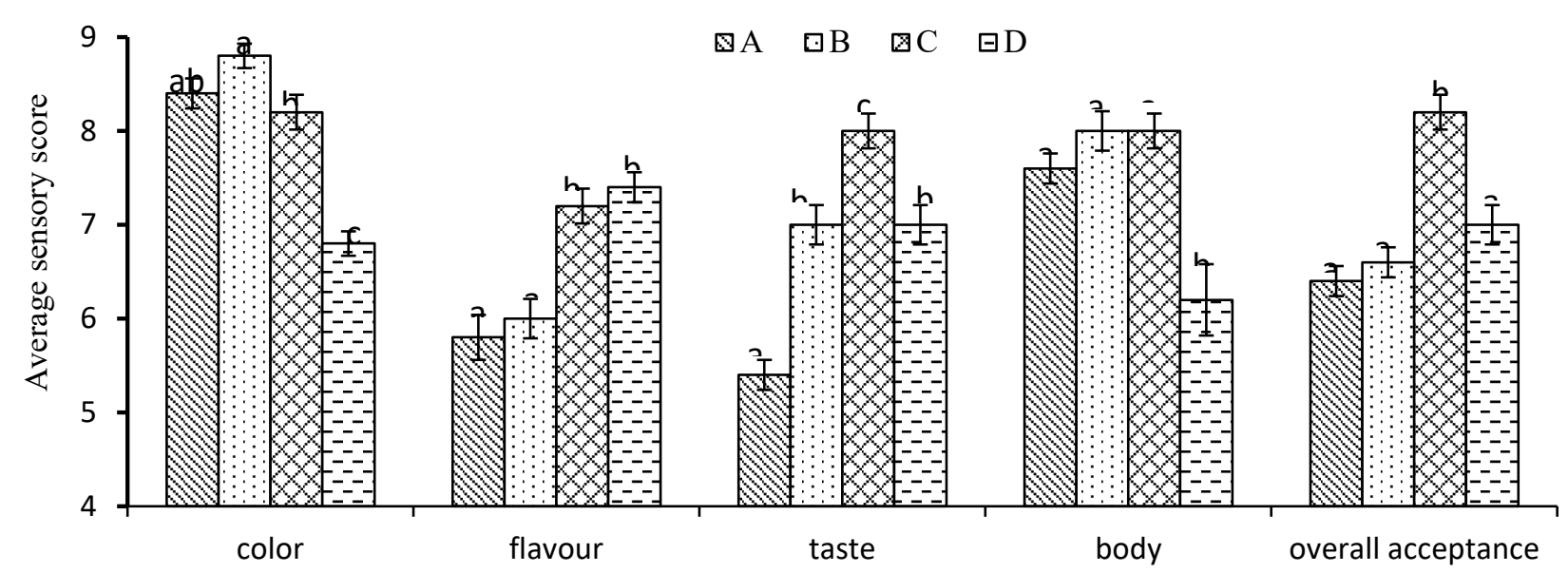

Fig 2. Sensory Score of beverages prepared by incorporating whey and mango pulp Different letter on the bar under same heading is significantly different at $(p \leq 0.05)$

sensory score for flavor was found to follow a decreasing pattern. Product C (69.9:20) has got the highest score on most of the important parameters. Product $\mathrm{C}$ was found to be superior to other products in taste, body and overall acceptance

\section{Conclusion}

As per our study, the whey and mango pulp ratio of 69.9:20 (with $10 \%$ sugar and $0.1 \%$ CMC at $0.3 \%$ acidity level) was found to give the beverage with best sensory score. The color, flavor and storage properties of the whey beverage was found good. The sugar and mango pulp were able to mask the undesirable flavor of whey, making it possible to utilize byproduct (i.e. whey). Further study on shelf-life of this product is encouraged.

\section{References}

Beucler, J., Drake, M. and Foegeding, E.A. (2005). Design of beverage from whey permeate. J. Food Sci., 70(4): 52775285.

Cruz, A. G., Ana, A. S. S., Macchione, M. M., Teixeira, A. M., Schmidt, F. L. (2009). Milk drink using whey butter cheese (Queijo manteiga) and Acerola juice as a potential source of vitamin C. Food and Bioprocess Technology, 2: 368-373.

Dalgleish, D. G., Mourik, L. van and Corredig, M. (1997). Heatinduced interaction of whey proteins and casein micelles with different concentration of $\alpha$-lactalbumin and $\beta$-lactoglobulin. J. Agric. Food Chem. 45:48064813.

Ingale, M. P., Ranveer, R. C., Nagargoje, K. D. (2009). Development of whey based custard apple (Annona Squamosa L.) beverage. Beverage Food world. 36: 4344.

Koffi, E., Shewfelt, R. L., Wicker, L. (2005). Storage stability and sensory analysis of UHT-processed whey-banana beverage. J. Food Quality. 28 (4): 386- 401.
Kravchenko, E. F. (1988). Whey beverages. IDF Bull 233:61-67.

Naik, Y. K., Khare, A., Choudhary, P. L., Goel, B. K., Shrivastava, A. (2009). Studies on physico-chemical and sensory characteristics of whey based watermelon beverage. Asian Journal of Research in Chemistry, 2: 5759.

Patel, S., Prashant, S., Choudhary, P. L., Bakane, P. H. (2006). Development and evaluation of whey based mango herbal (ginger) beverages. Beverage Food World, 33: $15-19$.

POPOVIĆ-VRANJEŠ, A., and VUJIČIĆ, I. F. (1997). Tehnologija surutke. Poljoprivredni fakultet, Novi Sad.

Rainha, N., Lima, E., Baptista, J. and Rodrigues, C. (2011). Antioxidant properties, total phenolic, total carotenoid and chlorophyll content of anatomical parts of Hypericum foliosum. J. Medicinal Plants Res. 5 (10), pp. 1930-1940.

Ranganna, S. (2008). "Handbook of analysis and quality control for Fruits and vegetable products" (2nd ed.). Tata McGraw -Hill publishing Company Ltd., New Delhi, India.

Sakhale, B.K., Pawar, V.N., Ranveer, R.C. (2012). Studies on the development and storage of whey based RTS beverage from Mango cv. Kesar. J. Food Process Technol., 3: 148.

animegalai, G. (2005). Studies on storage stability of whey based papaya juice blended RTS beverage. J Food Sci Technol. 42: 185-188.

Shekilango, S. A., Jelen, P., Bagdan, G. C. (1997). Production of whey-banana beverages from acid whey and over ripe bananas. Milchwissenschaft, 52: 209212.

Sherwood, S., Jenkins, D. (2007). Whey- based beverages- a new generation of dairy products. Mijekarstvo/ Dairy, $\mathbf{5 8}$ (3): 257- 274.

Yadav, R.B., Yadav, B.S. and Kalia, N. (2010). Development and Storage Studies on Whey-Based Banana Herbal (Mentha arvensis) Beverage. American J. Food Technol, 5(2): 121-129. 